\title{
Geologic and Geophysical Observations In the Northern Labrador Sea
}

\author{
G. LEONARD JOHNSON*, AL W. CLOSUIT $\dagger$ AND JAMES A. PEW*
}

\begin{abstract}
Recent investigations have yielded valuable information as to the morphology, structure and origin of the northern Labrador Sea. Indirect evidence indicates bottom current regimes may well control the dynamic processes of sedimentation. The buried Mid-Labrador Sea Ridge was traced to the sill of Davis Strait. It is postulated that this ridge represents a relic Mid-Oceanic Ridge which through axial growth separated the continental blocks of Greenland and Canada.
\end{abstract}

RÉSUMÉ. Observations géologiques et géophysiques dans le nord de la mer du Labrador. Des recherches récentes ont fourni de précieuses informations sur la morphologie, la structure et l'origine de la partie nord de la mer du Labrador. Des preuves indirectes indiquent que les régimes des courants de fond pourraient bien déterminer les processus dynamiques de sédimentation. La crête enfouie au milieu de la mer du Labrador a été retracée jusqu'au seuil du détroit de Davis. On peut considérer que cette crête représente les restes d'une crête médi-océanique dont la croissance axiale a séparé les blocs continentaux du Groenland et du Canada.

\begin{abstract}
PE3ЮМЕ. Геологические и геофизические наблюдения в Северном Лабрадорском море. Наблюдения, проведенные в последнее время, дали ценную информацию по морфологии, структуре и проиехождению Северного Јабрадорского моря. Косвенные данные указывают на то, что режғимы донных течений, возможно, обусловливают динамические процессы седиментации. Погребенный СрединноЈабрадорский Морской хребет был прослежен до порога Девисова пролива. Высказывается предположение, что этот хребет предетавляет собой реликтовый Срединно-Океанский хребет, который, разрастаясь в осевом направлении, разъединил континентальные блоки Гренландии и Канады.
\end{abstract}

\section{INTRODUCTION}

The Labrador Sea has been investigated by numerous oceanographic expeditions. Of prime interest to the physical oceanographer are two major current systems (Smith et al. 1937). The West Greenland Current flows northward along the coast carrying polar water from Denmark Strait. Admixture of Atlantic water gives the polar water a relatively high salinity of 35 per cent. The Labrador Current transports cold, low-salinity water from Baffin Bay southward along the western side of the Labrador Sea. South of Davis Strait, a branch of the West Greenland Current gyres to the west (Soule et al. 1963) Fig. 1.

Despite the advanced state of knowledge of the water masses, marine geology has remained relatively untouched. The most comprehensive geological study was by Manchester (1964). The present paper is the result of a geological/geophysical reconnaissance survey of the region. In addition, use has been made of sounding data from: The International Hydrographic Bureau (GEBCO Sheet 6); U.S.

* Global Ocean Floor Analysis and Research Project, U.S. Naval Oceanographic Office.

$\dagger$ Magnetic Division, U.S. Naval Oceanographic Office. 




FIG. 1. Cross section of temperature isotherms in the Labrador Sea. Note the steep temperature gradients bounding the two current systems which is indicative of a relatively high velocity - after Soule et al. 1963.

Naval Oceanographic Office (master sheet files); and the Bedford Institute of Oceanography.

During the months of August and September 1967, the United States Coast Guard Cutter Mariposa, in cooperation with the U.S. Naval Oceanographic Office and the University of Wisconsin, conducted a 3,500-mile magnetic, bathymetric and seismic reflection reconnaissance survey of the northern Labrador Sea.

Soundings were obtained with a Precision Graphic Recorder (Alden Model 418) and the echo distances, measured in units of $1 / 400 \mathrm{sec}$. travel time, are probably accurate to at least 1 part in 3,000. Soundings were read at every peak, trough or change in slope.

A nuclear resonance magnetometer (Varian 4931 DR) was employed to measure the absolute value of the earth's magnetic field. Magnetic tapes were scaled at 50 gamma intervals and at all magnetic highs and lows.

Seismic reflection measurements were taken using an air gun as the energy source. An air gun emits a high pressure bubble of compressed air into the water. The reflection of this pulse from the bottom layers is then picked up by a towed hydrophone array. Two sizes of air guns were employed: a 10 cubic inch Bolt Model PAR 600 and a 300 cubic inch Bolt Model PAR 1500.

Navigation was by LORAN A, celestial and radar fixes. LORAN A was generally unreliable, and celestial fixes were infrequent owing to poor weather. Radar fixes were limited to near-shore positions. Navigational accuracy was probably within 5 miles for most of the cruise.

\section{MORPHOLOGY}

The Mariposa survey was concentrated between $61^{\circ}$ and $64^{\circ} \mathrm{N}$. Data from other sources were used in the construction of the bathymetric chart (Fig. 2). 

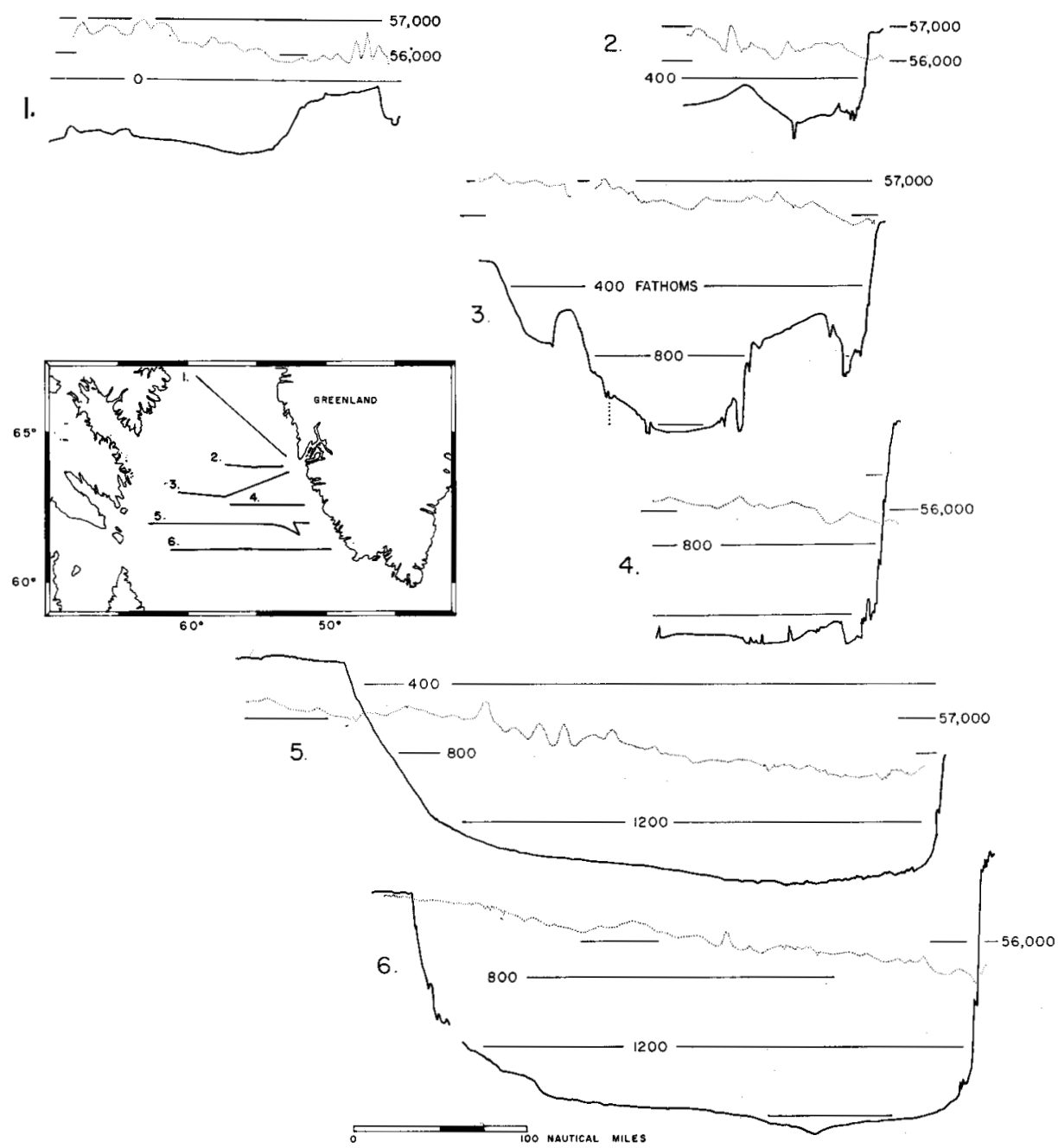

FIG. 3. Six topographic profiles across the Labrador Sea. Vertical exaggeration 100:1. Total intensity magnetic values are shown for each line.

Morphologically the northern Labrador Sea resembles a U-shaped valley. It is bounded to the north by Davis Strait at a depth of slightly more than 350 fathoms and to the east and west by the continental blocks of Greenland and Canada, respectively. The sea floor deepens southward, at an average gradient of approximately 1:240. Where the Labrador continental shelf break was observed, its depth ranged between 250 and 300 fathoms. Gradients on the adjacent continental slope ranged from 1:20 (Fig. 3, profile 6) to 1:40 (profiles 3 and 5). On all profiles an extensive and well-developed continental rise is present.

The Greenland Continental Shelf, with a shelf break lying close to the 100fathom isobath, is approximately 100 fathoms shallower than the shelf break off the east coast of Greenland (Johnson and Eckhoff 1966). The continental 
slope is precipitous $(1: 10)$ and the continental rise is poorly developed and irregular in form.

Unique topographic features found in the northern Labrador Sea are a number of sea floor canyons. One small V-shaped canyon at $62^{\circ} 50^{\prime} \mathrm{N}$., $57^{\circ} 45^{\prime} \mathrm{W}$. was traced northward and found to be only 22 miles long. It gradually shoaled at the northern and southern extremities, merging with the continental rise (Fig. 2). The absence of seismicity associated with the trench at the base of the Greenland Continental Slope at $63^{\circ} \mathrm{N}$., may indicate an erosional rather than a tectonic origin for this feature. This small marginal trench merges with a canyon and can be traced as far as $65^{\circ} \mathrm{N}$. (Fig. 2). The marginal plateau at $63^{\circ} 20^{\prime} \mathrm{N}$., $54^{\circ} \mathrm{W}$.
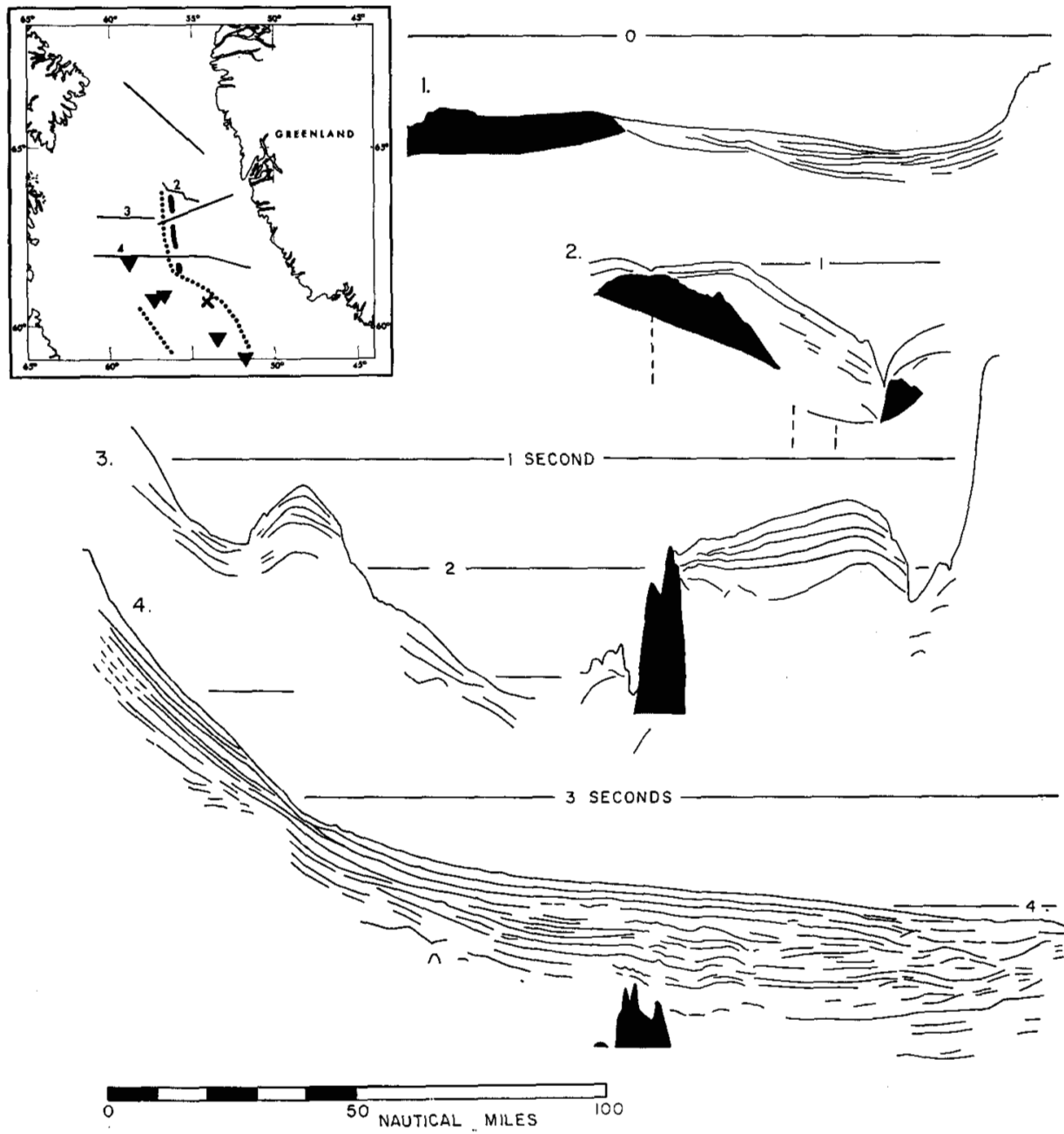

FIG. 4. Tracings of Profiles 1 to 4 Fig. 8. Assumed basement is dark coloured. Inverted triangles on index chart are earthquake epicenters; dotted lines indicate axis of high value magnetic anomalies (2); X marks axis of Drake, et al. profile C-D (1) basement high; heavy dashed line indicates axis of basement high. Travel is 2-way -1 second is approximately equal to one kilometre. (From Johnson and Pew 1968). 
appears to be the result of sediment ponding against protruding basement rock (Fig. 4, profile 3). The dominant sea-floor feature as far north as $60^{\circ} \mathrm{N}$., is the Northwest Atlantic Mid-Ocean Canyon (Heezen et al. in press).

\section{NORTHWEST ATLANTIC MID-OCEAN CANYON}

The Northwest Atlantic Mid-Ocean Canyon was discovered in 1949 by the Atlantis Cruise 157. In 1952 Lamont Geological Observatory investigators aboard the Kevin Moran and Atlantis established the continuity of the canyon from $38^{\circ} \mathrm{N}$. to $52^{\circ} \mathrm{N}$. (Ewing et al. 1953). In 1963 the Canadian vessels Sackville and Baffin traced the canyon to $59^{\circ} 45^{\prime} \mathrm{N}$. (Manchester 1964), to connect with some crossings by Drake et al. (1963) aboard the Vema near $61^{\circ} \mathrm{N}$.

The total length of the canyon is approximately 2,000 miles from the northern Labrador Sea to the Sohm Abyssal Plain (Fig. 5). The canyon is typically boxshaped with a flat floor and steep walls. At its southern end, the canyon becomes indistinct upon reaching the Sohm Abyssal Plain. Between $51^{\circ}$ and $39^{\circ} \mathrm{N}$. the canyon floor has a gradient of 1:2250 (Heezen et al. 1959). Farther north the canyon declivity increases to 1:1800 (Manchester 1964).



FIG. 5. Extent of mid-ocean canyon. Dashed lines indicate probable tributaries (after Heezen et al. 1959).

The west levee of the canyon is consistently about 10 fathoms higher than the east (Fig. 6). Bates (1953) studied the effect of the Coriolis force in the formation of deltas and proposed that the upper surface of a given flow will tilt with the lower side on the left in the northern hemisphere (Menard 1964). A turbidity current flowing down the canyon will be contained by its walls so that it cannot curve to the right; however, the surface of such a southward flowing current should dip east. The higher western levee fits these theoretical suggestions as does the westward bend of the canyon at $37^{\circ} \mathrm{N}$. The eastward strike of the canyon at $51^{\circ}$ may be a deflection around the protruding continental block of Nova Scotia. 


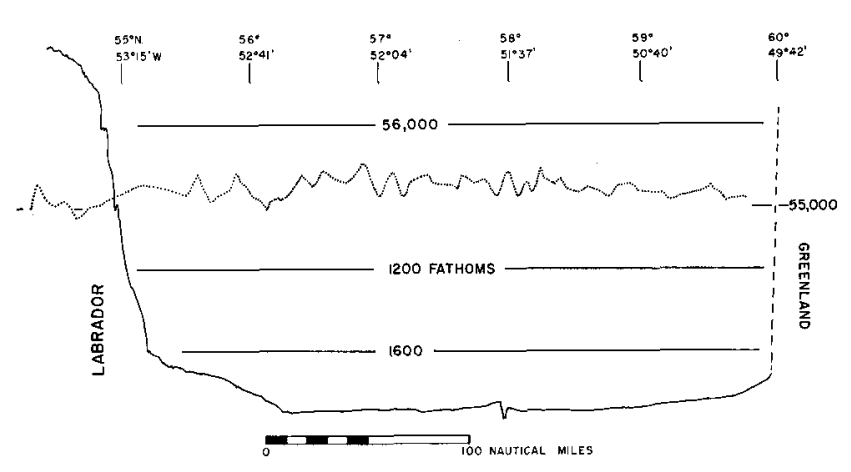

FIG. 6. Topographic profile at 100:1 vertical exaggeration across the Labrador Sea. Note the general symmetry of the magnetics, the two regions of high anomalies and the prominent mid-ocean canyon.

The Mariposa cruise of 1967 collected additional data on the northern extremity of the canyon. The source of the mid-ocean canyon has been unknown, with either Hudson or Davis Strait being favoured by most investigators. The results of the Mariposa cruise definitely favour the Davis Strait origin with perhaps a tributary emanating from Frobisher Bay. Manchester (1964) believes that the canyons on the continental slope seaward of Frobisher Bay are more likely to be related to the graben structure of that bay. Fig. 2 shows the mid-ocean canyon to be clearly defined at $60^{\circ} \mathrm{N}$., $55^{\circ} 30^{\prime} \mathrm{W}$. It apparently bifurcates at $60^{\circ} 30^{\prime} \mathrm{N}$., $57^{\circ} 30^{\prime} \mathrm{W}$. with one channel striking towards Frobisher Bay and the other branch heading towards the west side of Davis Strait. Fig. 7 traces what is apparently a continuous canyon (profiles 1 to 3 ) to the well-defined portion of the mid-ocean canyon: profile 4 . Profiles 2 and 3 are admittedly very subtle, topographic expressions; however, the authors believe them to be a continuous feature.

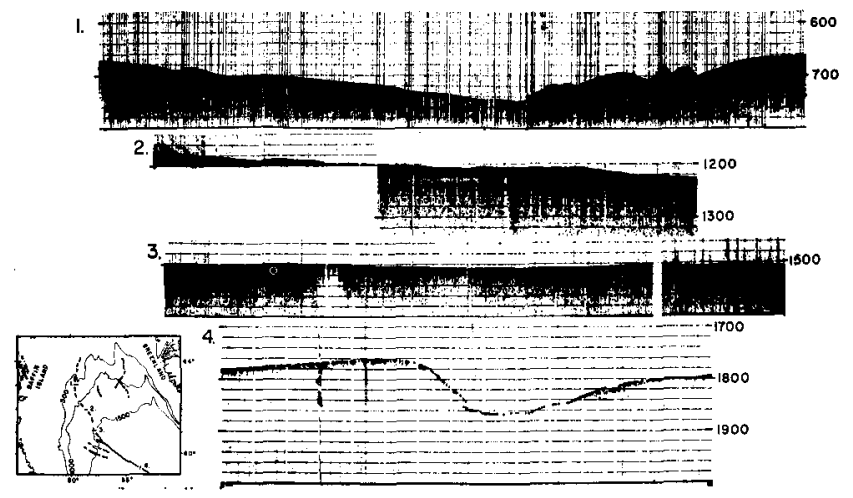

FIG. 7. Four sections of PGR (Precision Graphic Recorder) records across the northern extension of the mid-ocean canyon.

Heezen et al. (1969) point out that the large quantity of sediment required to build the levéed banks of the canyon (Fig. 6) can be most easily explained by utilizing the glacial melt waters of the Canadian interior draining through Hudson Strait in Pleistocene time. Baffin Bay on the other hand, seems an unlikely candidate as a prime sediment source.

The deep trench along the base of the continental slope of Greenland may also have been an active tributary (Fig. 3, profiles 2 to 4 ). We have, as yet, no evidence for either a historical or present-day topographic connection between this mar- 
ginal trench and the mid-ocean canyon.

Geostrophic bottom currents whose importance in sculpting the continental rise have only recently been recognized (Heezen et al. 1966) may have recently filled in the canyon in the two central profiles (Fig. 7, profiles 2 to 3). Off Cape Hatteras, the southerly-flowing Western Boundary Undercurrent has measured speeds with an average of about $18 \mathrm{~cm}$. sec. (Heezen et al. 1966). This speed can transport all the finer sediment sizes (Heezen and Hollister 1964). The presence of an undercurrent in the Labrador Sea is indicated by the strong inclination of the deep isotherms (Fig. 1).

\section{STRUCTURE}

Drake et al. (1963), reported two seismic reflection traverses of the Labrador Sea. Their profiles suggested an apparently continuous buried ridge near the

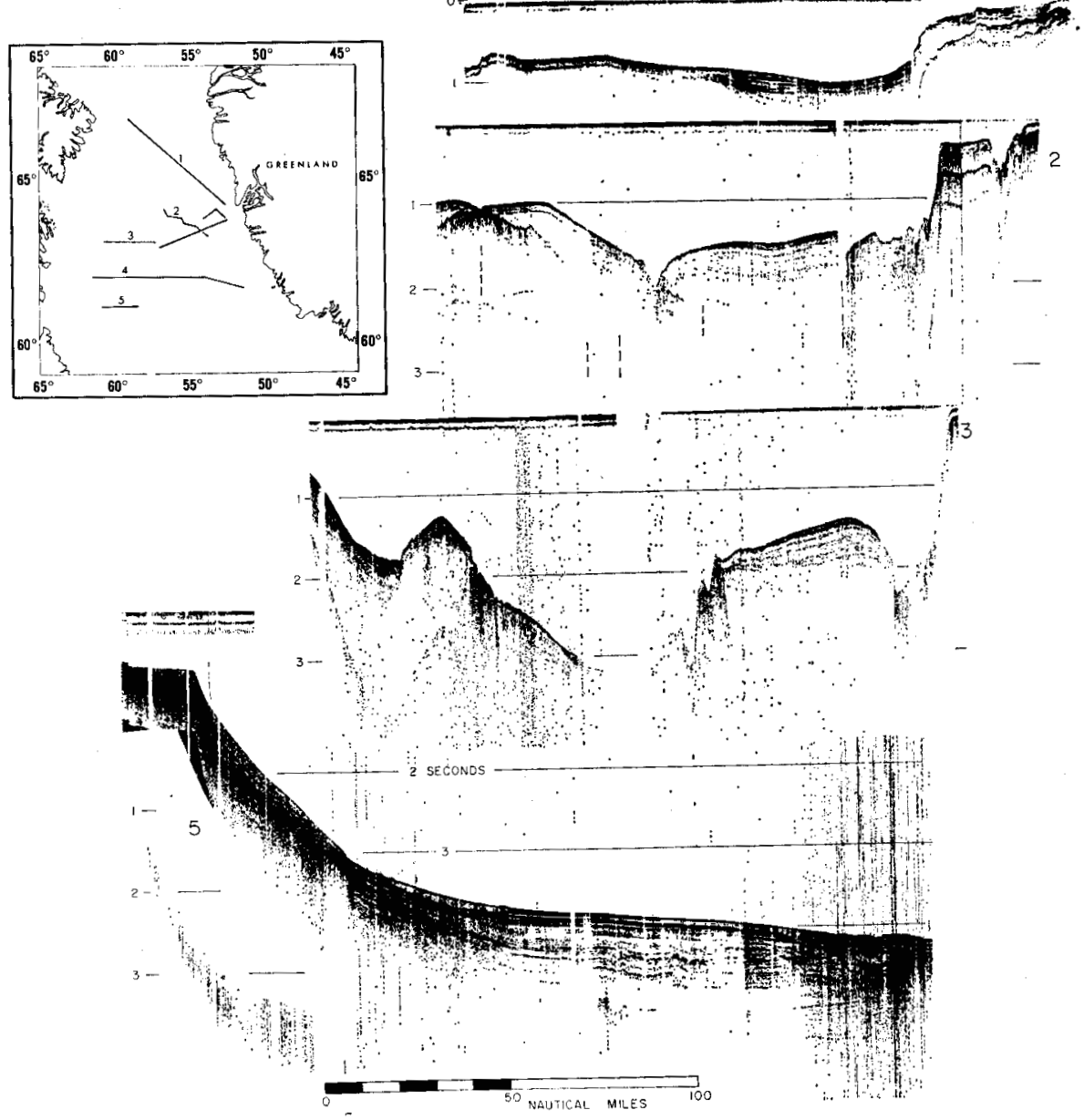

Fig. 8. Five seismic reflection traverses of the northern Labrador Sea. Travel time is 2-way -1 second is approximately equal to one kilometre. 
geographic axis of the basin. This Mid-Labrador Sea Ridge was interpreted to be an extinct branch of the Mid-Atlantic Ridge. Seismic refraction measurements (Drake et al. 1963), add further support to this interpretation. The P-wave velocity structure under the Labrador Basin resembles that of the Mid-Atlantic Ridge (Ewing and Ewing 1959), rather than the typical ocean basins.

Between $61^{\circ}$ and $62^{\circ} \mathrm{N}$. the crest of the ridge is overlain by a kilometre of sediment (Fig. 8, profile 4 and Drake et al. 1963, profile C-D). To the south where sediment accumulation rates may be lower, the crest outcrops as isolated knolls on the sea floor. North of $62^{\circ}$ the crest is covered by a thinner veneer of sediment (Fig. 8, profiles 2 and 3). The flanks of the ridge are deeply buried near the continental margins of Greenland and Canada, where sediment thicknesses exceed 2 kilometres (Drake et al. 1963).

The Mariposa data apparently extend the known extent of the ridge to at least $64^{\circ} \mathrm{N}$. The basement high, presumably the $5.5 \mathrm{~km}$. $/ \mathrm{sec}$. material of Drake et al. (1963), must strike NNW. near $55^{\circ} \mathrm{W}$. if it continues from profile C-D of Drake et al. This buried ridge axis lies slightly to the east of a line bisecting that part of the Labrador basin which lies between the continental shelves (Fig. 8). In profile 3 (Fig. 4 and 8), the structural high has apparently acted as a partial dam for detritus. Near $64^{\circ}$ the high has almost reached the surface and its rugged relief is replaced by a monolithic-appearing swell. This large lava effusion perhaps occurs at the junction of two major tectonic trends: the Mid-Oceanic Ridge and the Brito-Arctic Tertiary basalt province.

The base of the Greenland Continental Slope is occupied by a small trench. The sedimentary layers below the trench appear to be disturbed and perhaps eroded (Fig. 8, profile 3) although the reflection records are difficult to interpret. Small normal step faults were discovered on the Greenland slope (Fig. 8, profile 1) which are typical of rifted continental margins.

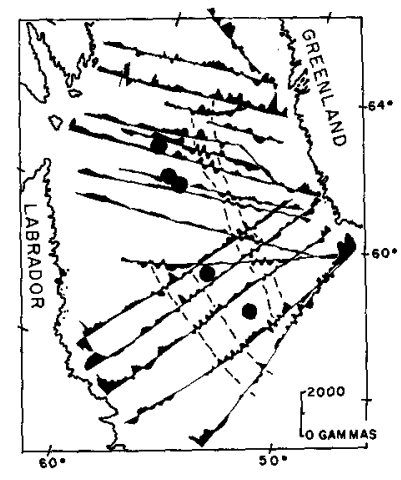

FIG. 9. Magnetic profiles from Godby et al. 1966 with Mariposa lines added. Note the two regions of high anomalies. Large circles earthquake epicenters.

\section{MAGNETICS}

Correlation of the buried Mid-Labrador Ridge with magnetic anomalies has been attempted by Godby et al. (1966). These investigators found two belts of relatively broad, high amplitude anomalies flanking a central swath of lower 
amplitudes. Several epicenters fall within this quiet zone (Sykes 1965). The aeromagnetic residual profiles of Godby et al. (1966) have been added to the Mariposa lines and correlate well (Figs. 6 and 9). South of $60^{\circ} \mathrm{N}$. the two disturbed belts are characterized by $15 \mathrm{~km}$. wavelengths and 300 gamma amplitudes. The western magnetic belt does not appear to extend north of $60^{\circ} \mathrm{N}$. Its abrupt termination at $60^{\circ} \mathrm{N}$. may bear evidence to a fracture zone, striking $050^{\circ}$ which would also offset the basement high (Fig. 4) at $61^{\circ} 30^{\prime}$ where the buried ridge apparently changes direction to N-S. Similar abrupt terminations are observed where the Mason-Raff lineations intersect the California coast (Mason and Raff 1961). The eastern magnetic zone can be easily traced to $64^{\circ} \mathrm{N}$. (Fig. 9) where it merges with the Davis Strait sill structure.

The frequency of earthquakes in the northern Labrador Sea is at most 10 per cent that of normal crestal regions of the Mid-Oceanic Ridge (L. Sykes, personal communication) and all fall within the low anomaly central zone (Fig. 9). It therefore seems plausible that these few earthquakes reflect slight residual activity on the inactive Mid-Labrador Ridge. Alternatively, the earthquakes may be associated with an extension of the Cumberland Sound graben structure into the Labrador Basin (Kerr 1967).

The undisturbed axial field could be due to a spreading rate either very high or very low compared with the frequency of polarity reversals. As the ridge is now inactive it seems probable that the axial swath is the result of crust generated while spreading rates declined to zero. The magnetic signature of the Labrador Sea resembles that observed by Avery et al. (1968) across a postulated fossil rift in the Norwegian Sea (Johnson and Heezen 1967). An axial swath of low amplitudes is observed in the latter case as well. Alternatively because the eastern magnetic zone is associated with the structural high, and lies close to the geographic axis (Fig. 4), it may represent the axis of the Mid-Oceanic Ridge.

In the northern Labrador Sea the basement high corresponds with the eastern magnetic anomaly zone. If the basement high represents the rift mountains, the western rift mountains are presumably too deeply buried by detritus or were poorly developed. However, if one assumes the Mid-Oceanic Ridge axis to be equidistant from the edges of the continental blocks, the basement high must be the axis (Fig. 4). On the other hand it should be noted that the Mid-Atlantic Ridge does not everywhere bisect the ocean basin (Johnson and Heezen 1967). Heezen and Tharp (1968) have postulated that a major fracture zone of the MidAtlantic Ridge curves to the northwestward through the axis of the northern Labrador Sea. The basement high would then be a fault scarp. Further work will be required in the southern Labrador Sea to prove or disprove this hypothesis.

In the southern Labrador Sea, Mayhew et al. (1968) assumed that the axis of magnetic symmetry represents the former ridge axis, as would be expected by the Vine-Matthews Theory (Vine and Matthews 1963). This Magnetic axis lies within the magnetically quiet zone. Mayhew further suggested the youngest belt anomaly corresponds to event 27 approximately 65 million years B.P. (late Cretaceous) and the flank anomalies extend to event 32 nearly 80 million years B.P. (Heirtzler et al. 1968). Mayhew also postulated a spreading rate of $2 \frac{1}{2} \mathrm{~cm} . / \mathrm{yr}$. for this branch of the Mid-Oceanic Ridge, while it was active during late Creta- 
ceous time. The authors identified the basement high as the crestal portion of the now extinct ridge. Burial by over a kilometre of sediment indicates a relatively great age for this feature. Exact sedimentation rates are hard to predict; however, they must be high due to the active biologic productivity and sediment load carried by the Western Boundary Undercurrent. Mayhew's age (65 m.y. B.P.) for the last segment of crust generated by the Mid-Labrador lift before it became inactive implies an average sedimentation rate of about $2 \mathrm{~cm} . / 1000 \mathrm{yrs}$.

\section{DISCUSSION}

In conclusion, the bottom conditions of the northern Labrador Sea give indication of major sculpting by bottom currents. The Labrador Current has a velocity of approximately $20 \mathrm{~cm}$./sec. seaward of Ellesmere Island (Kiilerich 1939) and accelerates to velocities of over $70 \mathrm{~cm}$./ sec. off Labrador (Plutchak 1966; Kollmeyer 1967). Velocities of $25 \mathrm{~cm}$./sec. have been recorded by the West Greenland Current off the southern tip of Greenland (Fig. 1; Ichiye and Fairbridge 1966). In Figs. 4 and 8, profile 1, the Labrador Current has apparently swept the basement rock bare of all loose sediment, whereas to the east, the weaker West Greenland Current has deposited sediment lenses in the elbow at the base of the Greenland Continental Slope. If neither current extends much deeper than 700 metres, the deeper erosional processes must be controlled by the Western Boundary Undercurrent. The inclined isotherms of the Labrador Sea at depths greater than 1500 metres bear evidence to the existence and probably high velocity of this undercurrent. Apparently the undercurrent has smoothed the sea floor and filled in the mid-ocean canyon between the $800-1550 \mathrm{fm}$. $(1460-2730 \mathrm{~m}$.) isobaths within the area of Fig. 2.

The origin of the marginal trench lying at the base of the Greenland Continental Slope to the seaward of Godthaab is either tectonism, erosion by bottom currents, or a combination. In favour of tectonism is the abnormally shallow depth of the Greenland Continental shelf, despite the heavy ice load on Greenland itself, and the distortion of the sub-bottom layers along the axis of the trench (Fig. 8).

It was suggested by Heezen et al. (1966) that the Gulf Stream actually touches bottom at depths of up to 4,000 metres, so perhaps the West Greenland Current likewise is flowing on occasion along the bottom in this region. If the current is sufficiently strong to erode fine material, the development of a normal continental rise would be precluded. Alternatively, a Western Boundary Undercurrent may be eroding the sediments at the base of the slope.

The mid-ocean canyon is a sedimentary feature, as is evidenced by the levees. The canyon sedimentation regime may at least on occasion be erosional, because of reported submarine cable failures (Heezen et al. 1959). The main source appears to be the western part of Davis Strait. The sinking of cold dense water of the East Labrador Current flowing southward through the Strait may well represent the headwaters of the canyon. The large canyon-like feature (Fig. 5, profile 1) supports this hypothesis. Sediment taken from the canyon floor near $40^{\circ} \mathrm{N}$. consists of the graded sands and silts indicative of turbidity current deposition (Ewing et al. 1953). The submarine cable failures reported by Heezen $e t$ al. 
(1959) off the Grand Banks occurred near the axis of the mid-ocean canyon and bear dramatic witness to processes along the floor of the canyon.

The seismic reflection data do not support the hypothesis (Kerr 1967; Rvachev 1967) that a submerged continental remnant floors the Labrador Sea. The axial position of the crest instead suggests the creation of Baffin Bay by ridge growth (Johnson and Heezen 1967). As previously postulated by earlier investigators Nares Strait north of Greenland would act as a transform fault (Wilson 1963; Wegener 1924), connecting the Labrador branch with the Arctic branch of the Mid-Oceanic Ridge. The presence of Cretaceous marine fossils on the southwestern Greenland shelf (Rvachev 1964) would suggest that a shallow epicontinental sea area between Greenland and Labrador was formed in early Cretaceous by initial rifting of the continental blocks. N. J. McMillan (Tenneco Oil and Minerals, Ltd., personal communication) suggests initial separation may have begun as early as Jurassic.

\section{ACKNOWLEDGEMENTS}

The cooperation of the officers and crew of the USCGC Mariposa and members of the scientific party John Jacobsen (U.S. Naval Oceanographic Office), Jim Kosalos and Bertrand Tanner (University of Wisconsin) is gratefully acknowledged. Sounding and magnetic data supplied by $\mathrm{K}$. Manchester were most valuable. Dr. B. C. Heezen provided unpublished Lamont Geological Observatory echo soundings. P. R. Vogt and E. D. Schneider reviewed the paper and offered many helpful suggestions. This work was supported by the U.S. Naval Oceanographic Office and the Geophysical and Polar Research Center of the University of Wisconsin under Arctic Institute of North America/ONR grant 400.

\section{REFERENCES}

AVERY, O. E., G. D. BURTON and J. R. HEIRTZLER. 1968. An Aeromagnetic Survey of the Norwegian Sea. Journal of Geophysical Research. 73(14): 4583-4600.

Bates, c. c. 1953. Rational Theory of Delta Formation. Bulletin of American Association of Petroleum Geologists, 37(9): 2119-62.

DRAKE, C. L., N. J. CAMPbell, G. SANDER and J. E. NAFE. 1963. A Mid-Labrador Sea Ridge. Nature, 200: 1085-86.

EWING, J. I. and M. EWING. 1959. Seismic Refraction Measurements in the Atlantic Ocean Basin, Mediterranean Sea, on the Mid-Atlantic Ridge and in the Norwegian Sea. Geological Society of America Bulletin, 70: 291-318.

EWING, M., B. C. HEEZEN, D. B. ERICSON, J. NORTHRUP and J. DORMAN. 1953. Exploration of the Northwest Atlantic Mid-Ocean Canyon. Bulletin of Geological Society of America, 64: 865-68.

GODBY, E. A., R. C. BAKER, M. E. BOWER, and P. J. HOOD. 1966. Aeromagnetic Reconnaissance of the Labrador Sea. Journal of Geophysical Research, 71(2): 511-17.

heEzen, B. C. and C. D. Hollister. 1964. Deep Sea Current Evidence from Abyssal Sediments. Marine Geology, 1: 141-74.

HEEZEN, B. C., C. D. Hollister, and W. F. RUDDIMAN. 1966. Shaping of the Continental Rise by Deep Geostrophic Contour Currents. Science, 152(3721): 502-08.

HEEZEN, B. C., G. L. JohNSON, and C. D. HOLIISTER. In press. The Northwest Atlantic Mid-Ocean Canyon. Deep Sea Research. 
HEezen, B. C. and M. THARP. 1968. Atlantic Ocean Floor. Painted by H. C. Berann, National Geographic Society, June 1968.

HeEzen, B. C., M. THARP and M. EWING. 1959. The Floors of the Oceans, I: The North Atlantic. Geological Society of America, Special Paper 65, 122 pp.

HeIRTZLeR, J. R., G. O. DicKinson, E. M. HERRON, W. C. PITMAN and X. LEPICHON. 1968. Marine Magnetic Anomalies, Field Reversals, and Motions of the Ocean Floor and Continents. Journal of Geophysical Research, 73: 2119-36.

ICHIYE, T. and R. W. FAIRBRIDGE. 1966. West Greenland Current. The Encyclopedia of Oceanography, edited by R. S. Fairbridge. New York: Rheinhold, 989 pp.

JoHNSon, G. L. and O. B. ECKHOFF. 1966. Bathymetry of the North Greenland Sea. Deep Sea Research, 13: 1161-73.

JOHNSON, G. L. and B. C. HEEZEN. 1967. Morphology and Evolution of the NorwegianGreenland Sea. Deep Sea Research, 14: 755-71.

Johnson, G. L. and J. A. PEW. 1968. Extension of the Mid-Labrador Sea Ridge. Nature, 217: $1033-34$.

KERR, J. w. 1967. A Submerged Continental Remnant Beneath the Labrador Sea. Earth and Planetary Science Letters, 2: 283-39.

KIILERICH, A. B. 1939. A Theoretical Treatment of the Hydrographical Observational Material, The Godthaab Expedition. 1928, Meddelelser om Grønland, 78: $149 \mathrm{pp}$.

Kollmeyer, R. c. 1967. Contribution to and Effect of the Hudson Strait Outflow on the Labrador Current. United States Coast Guard Oceanographic Report 12, CG 373-12, pp. 1-15.

MANChESTER, K. S. 1964. Geophysical Investigations Between Canada and Greenland. Halifax: Dalhousie University, M.S. thesis.

MASON, R. G. and A. D. RAFF. 1961. Magnetic Survey off the West Coast of North America, $32^{\circ} \mathrm{N}$. latitude to $42^{\circ} \mathrm{N}$. latitude. Bulletin of the Geological Society of America, 72: 1259-66.

MAYHEW, M. A., C. L. DRAKE, and J. E. NAFE. 1968. Marine Geophysical Evidence for Sea Floor Spreading in the Labrador Sea. Transactions of American Geophysical Union, 49, $202 \mathrm{pp}$.

MENARD, H. W. 1964. Marine Geology of the Pacific. New York: McGraw-Hill. 271 pp. Plutchak, N. B. 1966. Labrador Current. The Encyclopedia of Oceanography, edited by R. W. Fairbridge. New York: Rheinhold, pp. 438-39.

RVACHEV, v. D. 1964 . Relief and bottom deposits of the shelf of southwestern Greenland. Deep Sea Research, 11: 646-53.

1967. On the Origin of the Mid-Ocean Canyon in the North Atlantic. (In Russian; English abstract.) Ikeanologiia, Akademiia Nauk SSSR, 7(3): 477-82.

SMITH, E. H., F. M. SOULE, o. MOSBY. 1937. The MARION and GENERAL GREENE Expedition to Davis Strait and Labrador Sea, 1928-31-33-34-35. U.S. Coast Guard Bulletin, 19, pt. 2, 259 pp.

SOUle, F. M., A. P. FANCESChetti, R. M. o'hagan and v. W. DRIGgers. 1963. Physical Oceanography of the Grand Banks Region, The Labrador Sea and Davis Strait in 1962. U.S. Coast Guard Bulletin, 48: 29-78.

SYKes, L. R. 1965. The Seismicity of the Arctic. Bulletin of Seismological Society of America, 55: 501-18.

VINE, F. J. and D. H. MATTHEws. 1963. Magnetic Anomalies over Oceanic Ridges. Nature, 199: 947-49.

WEGENER, A. 1924. The Origin of Continents and Oceans. New York: E. P. Dutton and Company. $212 \mathrm{pp}$.

wiLson, J. T. 1963. Hypothesis of Earth's Behavior. Nature, 198: 925-29. 